\title{
IRENA and IEA: Moving Together Towards a Sustainable Energy Future- Competition or Collaboration?
}

\author{
Federico Esu \\ PhD Candidate, Erasmus University School of Law \\ esu@law.eur.nl \\ Francesco Sindico \\ Reader in International Environmental Law, University of Strathclyde Law School \\ francesco.sindico@strath.ac.uk
}

\begin{abstract}
The aim of this article is to critically examine, from a legal perspective, the relationship between the International Energy Agency (IEA) and the International Renewable Energy Agency (IRENA). The IEA was established in 1973 in response to the global oil crisis. It currently has 29 member states. Its original mandate has been expanded to include ensuring reliable, affordable, and clean energy. IRENA was established in 2009. Its main objective is to promote sustainable use of all forms of renewable energy. With 138 member states, and many more in the process of accession, IRENA is becoming a truly universal organization. Both the IEA and IRENA focus their attention on sustainable energy. Is there an institutional overlap or an unnecessary duplication in scope? Are IRENA's activities in sustainable energy, which seemingly parallel those of the IEA, justified by its aims and global reach? By addressing these and related questions, the article discusses whether the relationship between the IEA and IRENA can be seen as competition or collaboration between these two organizations. This relationship is specifically analysed in the context of the UN Sustainable Energy for All Initiative.
\end{abstract}

\section{Keywords}

International Renewable Energy Agency (IRENA); International Energy Agency (IEA); renewable energy; energy governance; fragmentation; energy cooperation.

\section{Introduction}

Energy did not feature amongst the former Millennium Development Goals (MDGs), yet it now has a central place in the post-2015 Sustainable Development Goals (SDGs). ${ }^{1}$ This represents an important step forward in abandoning the false myth that only fossilfuel-based energy is reliable and secure, and that progress and development can be achieved only with traditional energy sources. The 2015 Paris Agreement on climate change itself constitutes an urgent call to accelerate a global energy transition, based on

\footnotetext{
${ }^{1}$ The Sustainable Development Goals are an intergovernmental set of aspiration Goals with 169 targets contained in paragraph 54 of the UN Resolution A/RES/70/1 of 25 September 2015. The SDGs are the successors to the Millennium Development Goals. Because energy is central to achieving the SDGs, and although energy was not picked up as an issue in 2000, it has now been embedded in the new SDG n. 7 on 'affordable and clean energy', supported also by the Sustainable Energy for All (SE4All) Initiative.
} 
renewable energy generation and higher energy-efficiency rates. ${ }^{2}$ If countries deliver on the promises laid out in Paris, a tectonic shift in how energy is produced and consumed must take place.

To help transition from the current unsustainable energy patterns to more sustainable ones, various international and regional institutions, non-governmental organizations, initiatives, partnerships, and programs have been established worldwide. Seen from an institutional point of view, the establishment of the International Renewable Energy Agency in 2009 is an important milestone and represents an increased focus on renewable energy on behalf of the international community. This relatively new intergovernmental organization can be regarded as the organization that could shape international action and governance in the area of renewable energy. Since its establishment, IRENA has been chosen by the UN to represent the renewable energy hub for the UN Sustainable Energy for All (SE4All) Initiative, and it has been invited to explore how an aspirational target of doubling the global renewable energy share could be put into practice. ${ }^{3}$

In parallel, the International Energy Agency, founded in 1974 in a different context and in a different global energy and political context, has increasingly intensified its work on sustainable energy ${ }^{4}$ to the extent that it is currently undergoing a process of modernization aiming to become the 'global hub for clean energy'. 5

It goes beyond the purposes of this article to discuss the whole spectrum of actors involved in the field of energy, in general, and renewable energy, in particular. Section 2 provides only an outline of that spectrum. Instead, we will focus on IRENA and the IEA and examine the relationship between these two organizations in the context of the emerging legal and institutional landscape related to sustainable energy, and more specifically renewables. It is important to guard against the unnecessary duplication of effort in an already congested global energy arena. The main goal of the article is to determine whether the relationship between the IEA and IRENA is one of competition, collaboration, or perhaps (un)foreseen complementarity and mutual support. Section 3 provides a brief overview of the two organizations, highlighting their scope from a legal perspective, in order to better understand their mandate and ascertain the extent of

\footnotetext{
${ }^{2}$ In one of its press releases during the Paris negotiations in December 2015 IRENA, for example, has stressed the importance of accelerating the deployment of renewable energy and increasing energy efficiency to tackle the challenge of climate change. See "IRENA Welcomes Paris Climate Agreement as "watershed for the global energy transition", Looks ahead to 6th Assembly to set global renewable energy agenda', at

$<$ http://www.irena.org/News/Description.aspx?NType=A\&mnu=cat\&PriMenuID=16\&CatID=84\&News $\mathrm{ID}=>39$.

${ }^{\overline{3}}$ Sustainable Energy for All (SE4All) Initiative, 'Our Hubs: IRENA Renewable Energy Hub', at $<$ http://www.se4all.org/hubs/irena/>.

${ }^{4}$ The International Energy Agency (IEA) website features a section dedicated to renewable energy, at $<$ http://www.iea.org/topics/renewables/>. See also Thijs Van de Graaf, 'Fragmentation in Global Energy Governance: Explaining the Creation of IRENA', Global Environmental Politics, Volume 13, Number 3, August 2013, 14-33, at 25.

${ }^{5}$ IEA, 'IEA chief receives support in Brussels for modernisation push', 22 September 2015, at $<\mathrm{http}$ :/www.iea.org/newsroomandevents/news/2015/september/iea-chief-receives-support-in-brusselsfor-modernisation-push.html>.
} 
possible overlap. In section 4, the role of IRENA in leading the SE4All Initiative will be analysed. This section includes discussion on whether the IEA plays, or should play, a role in that initiative and whether SE4All tells us a story of institutional coordination, mismatch, or something else in the relationship between IRENA and the IEA. We conclude that the mandate and scope of the two organizations overlap in their quest to promote sustainable energy governance. The extent to which this overlap will lead to competition or collaboration between IRENA and the IEA will depend on how sustainable energy itself is defined and approached.

\section{IRENA and IEA in the Institutional Landscape of Sustainable Energy}

In the absence of a comprehensive international legally binding instrument on renewable energy, the existing energy-related legal instruments and institutions ${ }^{6}$ have sought to fill the gaps in renewable energy governance. These developments, however, have led to an increasingly dense legal and institutional structure resulting in functional overlaps and fragmentation. ${ }^{7}$ When it comes to assessing the international institutional setting in the field of renewable energy, at first glance, the participants in this setting seem to contribute to its fragmentation. Several organizations active in the energy, environmental, and sustainable development sectors have started to expand their scope and pay more attention to renewable energy promotion and development. ${ }^{8}$ Several UN specialized agencies and programs such as the UNDP, UNEP, the UN Department of Economic and Social Affairs, the UN Industrial Development Organization, UNEnergy, and the World Bank work to foster a transition to a low-carbon economy. Outside the UN, international organizations such as the OECD, the IEA itself, and international financial institutions, as well as IRENA, are also playing a role in addressing issues in renewable energy and energy efficiency, promoting financial and technology transfer, and encouraging research and development and international cooperation in general. Moreover, political fora such as the International Energy Forum,

\footnotetext{
${ }^{6}$ Such as, for example, the international climate change regime with the UNFCCC and its Kyoto Protocol, the Energy Charter Treaty and its Protocol on Energy Efficiency and Related Environmental Aspects (PEEREA), and several other, non-binding instruments that implicitly or explicitly reference energy (i.e. 'Agenda 21', 1992).

${ }^{7}$ Regime interplay and the fragmentation of international energy and environmental law are just an aspect of a wider phenomenon in International Law. For an overview of fragmentation and regime interplay see Fariborz Zelli, 'Institutional fragmentation', Zelli, Fariborz, Pattberg, Philipp Encyclopedia of Global Environmental Governance and Politics, Edward Elgar, 2015, 469-477; and Harro van Asselt, The Fragmentation of Global Climate Governance Consequences and Management of Regime Interactions, Edward Elgar, 2014. For an in depth analysis of fragmentation in International Law more generally see the report of the UN International Law Commission, 'Fragmentation of international law: difficulties arising from the diversification and expansion of international law, Report of the Study Group of the International Law Commission', ILC, Fifty-eighth session, 2006,

$<$ http://legal.un.org/ilc/documentation/english/a_cn4_1682.pdf $>$. For an overview on the fragmentation of energy governance see, inter alia, David Victor and Linda Yueh, 'The New Energy Order. Managing Insecurities in the Twenty-first Century', Foreign Affairs, 89(1), 2010; Gonzalo Escribano, 'Fragmented Energy Governance and the Provision of Global Public Goods', Global Policy, 2015.

${ }^{8}$ See Stuart Bruce, 'International Law and Renewable Energy: Facilitating Sustainable Energy for All?', 14 Melbourne Journal of International Law, 18, 2013; see also Heike Krieger and Claas de Boer with Helga Steeg, 'International Organizations and Their Activities in the Energy Sector', Energy Law in Europe: National, EU and International Regulation, edited by M. Roggenkamp, A. Ronne, C. Redgwell, I. del Guayo, OUP, 2001.
} 
the World Future Energy Summit, the G20, and the G8, as well as the periodic International Renewable Energy Conferences, constitute platforms for discussion and for ministerial statements on energy-related matters and sustainable development. Nonstate actors have also influenced the development of international law related to sustainable energy. Multi-stakeholder initiatives such as the Renewable Energy and Energy Efficiency Partnership (REEEP) and the Renewable Energy Policy Network for the 21st Century (REN21) are two significant examples in this respect. Both are NGOs which offer important platforms for knowledge-sharing, advocacy, and policy and market acceleration for green growth.

It has been argued that the establishment of partnerships, networks, conferences, memoranda of understanding, and voluntary commitments among the actors involved in the field of renewable energy may reflect 'the inherent difficulties of the UN system' and the 'dissatisfaction of some governments and other stakeholders with the role the UN System is able to play'. ${ }^{9}$ On the other hand, the creation and functioning of these initiatives may lead to stronger binding commitments and therefore strengthen rather than erode the UN system. It has been argued, for example, that new forms of international cooperation (beyond the traditional intergovernmental diplomacy) are gaining significant importance, and that new concepts of global governance are increasingly gaining momentum, particularly when it comes to tackling complex, contemporary challenges. ${ }^{10}$ What is paramount, however, is that the diverse initiatives and actors do not 'float around completely detached from one another or the formal international policy process'. ${ }^{11}$

\section{IEA and IRENA}

\subsection{Historical Origins and Negotiations}

The IEA and IRENA have very different origins. The IEA ${ }^{12}$ was established in 1974 to guard against the disruption of the energy supply by providing for stockpiling and emergency-sharing obligations. It signaled a shift from essentially unilateral responses to energy-supply disruption to a multilateral conception of, and response to, such disruption embedded in a binding treaty. ${ }^{13}$ The 1973 energy crisis, precipitated by OPEC's restrictions on production, ${ }^{14}$ had served to highlight the frailties of a unilateral,

\footnotetext{
${ }^{9}$ Paul H. Suding and Philippe Lempp, 'The multifaceted institutional landscape and processes of International Renewable Energy Policy', International Association for Energy Economics, 2007, at 6. ${ }^{10}$ Jens Martens, 'Multistakeholder Partnerships - Future Models of Multilateralism?', Occasional Papers, N. 29/January 2007, Dialogue on Globalization, Friedrich Ebert Stiftung, at 7.

${ }^{11}$ Paul H. Suding and Philippe Lempp, supra note 9, at 6.

${ }^{12}$ The definitive work on the IEA remains the two-volume treatment by a former legal adviser to the IEA, Richard Scott, IEA: The First Twenty Years (2 Vol., 1994); see also Heike Krieger and Claas de Boer with Helga Steeg, supra note 8; and the website of the IEA, available at $<$ http://www.iea.org $>$.

${ }^{13}$ See Catherine Redgwell, 'International Energy Law', in Energy Law in Europe: National EU and International Regulation, edited by M. Roggenkamp, C. Redgwell, I. del Guayo and A. Ronne, (Oxford: Oxford University Press, 2nd edition, 2007; 3rd edition, 2015).

${ }^{14}$ OPEC was established in 1960 at the joint initiative of Venezuela and Iraq, who were joined by Iran, Kuwait, and Saudi Arabia as founding members: see the Agreement establishing OPEC, 443 UNTS 248. The early 1970s saw a rise in OPEC's cartel-like powers over price and production, and it began setting oil prices without negotiation with oil companies. In 1973 Arab oil producers moved to deploy the 'oil
} 
non-binding approach. ${ }^{15}$ The Agreement on an International Energy Programme was signed by sixteen states in November $1974 .{ }^{16}$ It is open only to those members of the OECD able and willing to meet the requirements of the Programme, though cooperation with non-members such as Russia, China, and India has taken place. ${ }^{17}$ The Agency's primary mandate is to focus on the policies regarding the so-called 'three Es': energy security, economic development, and environmental protection. In addition, the IEA has increased its activities in the area of 'global engagement', which refers to the working relationships the Agency is establishing with countries beyond its membership, as well as with other international organizations and fora.

IRENA is a much younger organization than the IEA. Lobbying for an international organization for renewable energy began in the 1980s. ${ }^{18}$ IRENA was officially established in 2009. It was not a reaction to a specific event. It can be seen, rather, as a proactive long-term engagement of the international community in favour of increased generation of renewable energy.

\subsection{Membership}

A clear difference between the IEA and IRENA concerns their membership. The IEA consists of OECD states, and entry is by invitation. At the time of the 1973 crisis, key oil producers and exporters and major economies did not see any value in opening up the organization to a wider membership. This remains the case, with the IEA having 29 members, all of which are OECD states. ${ }^{19}$ The reason behind the creation of the IEA from within the OECD was also, according to some ${ }^{20}$ due to operational needs. Setting up the IEA in this way allowed the Agency to immediately commence its work to enhance cooperation in an oil emergency. ${ }^{21}$

IRENA has a much wider membership. ${ }^{22}$ Despite the fact that the push for its creation came from a handful of countries, led by Germany, Spain, and Denmark, the

weapon' of selective delivery and/or production cuts directed against Denmark, the Netherlands, Portugal, Rhodesia, South Africa, and the United States, precipitating the first energy crisis of 1973/74 and leading, inter alia, to the establishment of the IEA.

${ }^{15}$ See Catherine Redgwell, supra note 13.

16 The Agreement on an International Energy Program, which is the IEA constituent document, was amended on 9 May 2014.

${ }^{17}$ Art 71, IEA Agreement. There are presently 29 States that are members of the IEA (Estonia was the most recent to join, in 2014). For further background, including discussion of the legal status of the Agreement in international and domestic law, see Scott, supra note 26, Chapter 3.

${ }^{18}$ See Sybille Roehrkasten and Kirsten Westphal, 'IRENA and Germany's Foreign Renewable Energy Policy Aiming at Multilevel Governance and an Internationalization of the Energiewende?', Division Global Issues Stiftung Wissenschaft und Politik German Institute for International and Security Affairs, Working Paper FG 8, 2013/01, September 2013 SWP Berlin.

${ }^{19}$ IEA, 'Member Countries', at <http://www.iea.org/countries/membercountries/>.

${ }^{20}$ See, among others, Thijs Van de Graaf, 'Obsolete or resurgent? The International Energy Agency in a Changing Global Landscape', Energy Policy 48 (2012) 233-241; Richard Scott, 'The History of the International Energy Agency’, 1974-1994, Volume 2: Major Policies and Actions, 1995, Paris,

OECD/IEA, 41-42.

${ }^{21}$ See Thijs Van de Graaf, supra note 20.

${ }^{22}$ Almost all states joined the Agency. Canada and Hungary have not joined. These two are the only remaining IEA countries not to have joined IRENA. Other major non-member countries are Brazil and 
organization was thought of from the beginning as universal. ${ }^{23}$ It was not to be a forum for a handful of countries to shape renewable energy policy worldwide. ${ }^{24}$ The plan was for the organization to become a global hub of renewable energy excellence in which all countries could play a role. Our argument is that the move from a limited membership in the IEA to a global membership in IRENA is in line with other recent developments in international environmental law. While the MDGs focused only on the developing world, the SDGs and their targets apply to all, developed and developing countries alike. ${ }^{25}$ Similarly, the international climate change regime under the UNFCCC has moved towards a global approach with the adoption of the Paris Agreement. Whether this move to develop more inclusive regimes will lead to a more effective international environmental law, in the sense of actually solving the environmental problems at hand, remains to be seen; however, it does reflect a change in approach to global issues, at least from the days when the IEA was established.

\subsection{Scope}

Having clarified the origins of the IEA and IRENA and the different memberships of the two organizations, we now turn to their functions in the field of renewable energy in order to determine the extent of any overlap.

\subsubsection{IRENA and IEA: A Case of Overlapping Scope?}

Because of the nature of the two organizations, we find ourselves in a situation akin to lex specialis: the IEA has a broader remit that includes several energy-related matters, whereas IRENA has a much narrower mandate that focuses on renewables. ${ }^{26}$

As mentioned above, the IEA's mandate embraces four main areas: energy security, economic development (which includes the elimination of energy poverty), environmental awareness, and global engagement. ${ }^{27}$ The IEA's work on renewables is now linked to each of these areas. Energy-security challenges require identifying and developing energy sources that are safe, affordable, and reliable. Renewables face problems in this area, but, given time and resources, there is no reason why renewables could not contribute to dealing with energy security. Economic development is linked to renewables since a country can pursue an economic policy that favours renewable energy technologies and research and development. This could promote economic development, especially in the sense of sustainable development, with countries suffering from health and environmental hazards from fossil fuels benefiting from a

\footnotetext{
Venezuela.

${ }^{23}$ See Sybille Roehrkasten and Kirsten Westphal, supra note 18.

${ }^{24}$ See among others Johannes Urpelainen and Thijs Van de Graaf, 'The International Renewable Energy Agency: a success story in institutional innovation?', International Environmental Agreements, 15, 2015, at 170; Glen Wright, 'The International Renewable Energy Agency: A Global Voice for the Renewable Energy Era?', Renewable Energy Law \& Policy Review, at 251, 2011.

${ }^{25}$ See Jeffrey D. Sachs, 'From Millennium Development Goals to Sustainable Development Goals', The Lancet, Volume 379, Issue 9832, 9-15 June 2012, at 2206-2211.

${ }^{26}$ Johannes Urpelainen and Thijs Van de Graaf, supra note 24, at 167.

${ }^{27}$ See Thijs Van de Graaf and Dries Lesage, 'The International Energy Agency after 35 years: Reform needs and institutional adaptability', Review of International Organisations (2009) 4:293-317. See further $<$ www.iea.org/aboutus/whatwedo/ $>$.
} 
switch to cleaner forms of energy. Lastly, renewables are a response to an increased global environmental awareness.

One rationale for countries to develop a self-standing organization for renewables was that the IEA was deemed unfit for the task, despite its evolving mandate towards renewables. Many countries receiving support for renewables, such as countries in SubSaharan Africa, are absent from the IEA. So it was not just that the IEA was not deemed an appropriate organization because of its concern with multiple sources of energy; its restricted membership precluded it from being seen as the natural hub for renewables. ${ }^{28}$

Drawing on the model of the International Atomic Energy Agency, the idea behind IRENA was to create an intergovernmental organization that would foster cooperation in renewable energy production and development. ${ }^{29}$ Its statute confers a mandate to promote 'the widespread and increased adoption and the sustainable use of all forms of renewable energy'. ${ }^{30}$ Wide though this may seem, it is still less than dealing with all forms of energy, which is what the IEA does.

In this article we will not analyse the legal nature of IRENA's activities and outcomes. ${ }^{31}$ Suffice to say that at present IRENA does not create laws or policies for countries to consider or to follow; rather, it operates mainly as a clearing house, collecting information about development and deployment of renewables around the world. It also operates as an independent 'agent' that commissions and develops studies and services aimed at advancing knowledge in the field of renewable energy. In doing so, IRENA ends up overlapping not only with the IEA but also with organizations such as the IPCC $^{32}$ and bodies created under the UNFCCC; ${ }^{33}$ however, those other overlaps are beyond the scope of this article.

\subsubsection{Managing the Overlap Between the IEA and IRENA}

Before analyzing how the IEA and IRENA are attempting to manage the overlap in scope, a few words on how the IEA reacted to the launch and development of IRENA. In 2009, one option had been to develop an organization focusing on renewables within an already existing organization. ${ }^{34}$ The IEA had already set up a Working Group on

\footnotetext{
${ }^{28}$ Thijs Van de Graaf, 'Fragmentation in Global Energy Governance: Explaining the Creation of IRENA', Global Environmental Politics, Volume 13, Number 3, August 2013, 14-33, at 25; see also Sybille Roehrkasten and Kirsten Westphal, supra note 18.

${ }^{29}$ Hermann Sheer, 'Towards a Solar Proliferation Treaty. Leaving the Global Atomic Trap', in Updating international nuclear law, edited by H. Stockinger and E. van Dyje, Salzburg, 2007, 306-10.

${ }^{30}$ IRENA Statute, art. II 'Objectives'.

${ }^{31}$ In this regard, see, for example, the 'Annual report of the Director-General on the Implementation of the Work Programme and Budget for 2014-2015', A/6/3, 17 December 2015, available at $<$ http://remember.irena.org/sites/Documents/Shared\%20Documents/6th\%20Assembly/A_6_3_Annual\%2 0Report_17\%20Dec.pdf $>$.

${ }^{32}$ For example, the IPCC produced a Special Report 'Renewable Energy Sources and Climate Change Mitigation'. At <http://www.ipcc.ch/report/srren/>.

${ }^{33}$ Such as the SBSTA.

${ }^{34}$ One author has already assessed the costs associated with integrating IRENA into a broader institution and the costs of maintaining it independent. See Timothy L. Meyer, 'Epistemic Institutions and Epistemic Cooperation in International Environmental Governance', University of Georgia, School of Law,
} 
Renewable Energy Technology in the 1980s and had slowly integrated it into its activities. Yet, as noted, the IEA was deemed not to be an ideal host for IRENA due to restrictions on membership and an insufficient focus on renewable energy. The IEA's officials did not welcome the creation of IRENA. ${ }^{35}$ They criticized the trend towards fragmented energy governance based on the different sources of energy. ${ }^{36}$ One official argued that the most important task was to work towards common objectives, such as energy security and climate change mitigation, and that renewable energy is only a means to achieve those objectives, not a goal per se. ${ }^{37}$

Whether in reaction to the establishment of IRENA, or simply in order to maintain the momentum towards the promotion and development of renewable energy, in 2009 the IEA set up a division on renewable energy. ${ }^{38}$ To avoid overlaps and foster cooperation in this area, the IEA and IRENA entered into agreements according to which the two organizations would contribute to the development of databases on renewable energy policies, share information between them, and jointly organize technical and public events. $^{39}$

On paper, these post-2009 developments seem to go in the right direction. Two organizations interested in promoting renewables are working together and doing it in such a way as to keep themselves from stepping on each other's toes seems like good practice. Yet, on 22 September 2015, during a meeting with EU officials, Fatih Birol, the IEA's Executive Director, announced his plans to 'modernize the agency by building organic ties with emerging economies and by making the agency a global hub for clean energy'. ${ }^{40}$ One wonders how such intentions support the idea of the IEA and IRENA cooperating and not competing.

Research Paper Series, Paper No. 2013-06 February 2013. The author concludes that the governance costs for integrating IRENA into another broader institution would be higher than those of maintaining it independent. This is even more so if one considers the epistemic cooperation role played by IRENA. It would be preferable if IRENA keeps its independence in carrying out epistemic tasks.

${ }^{35}$ Thijs Van de Graaf, 'How IRENA is reshaping the global energy architecture', European energy Review, at <http://thijsvandegraaf.be/wp-content/uploads/2012/04/20120329-EER-How-IRENA-isreshaping-the-global-energy-architecture.pdf $>$.

${ }^{36}$ Fragmentation of international energy governance is deemed to be caused by, inter alia, the establishment of organizations that deals primarily with a single type of energy resource. For an overview on the causes of fragmentation of energy governance see, among others, Timothy L. Meyer, 'The Architecture of International Energy Governance', 106 Am. Soc'y Int'l L. Proc. 389, 2012.

37 Thijs Van de Graaf, supra note 28, at 26.

${ }^{38}$ IEA, 'Renewable Energy: Coming of Age', The Journal of the International Energy Agency, Issue 2, 2012 , at 10 .

${ }^{39}$ Johannes Urpelainen and Thijs Van de Graaf, supra note 24, at 171. In January 2012, the two Agencies signed a Letter of Intent which identifies three initial areas of co-operation: a) development and publication of a Joint Global Renewable Energy Policies and Measures Database, which expands on the existing IEA database to cover up to 150 countries, including all IRENA member countries; b) cooperation in technology and innovation, including the involvement of IRENA in the IEA Multilateral Technology Collaboration Network (Implementing Agreements); and, c) sharing of renewable energy statistics data and methods between the two organisations. See IEA website, FAQs, Renewable Energy, at $<$ http://www.iea.org/aboutus/faqs/renewableenergy/>.

${ }^{40}$ IEA, 'IEA chief receives support in Brussels for modernisation push', 22 September 2015, at $<$ http://www.iea.org/newsroomandevents/news/2015/september/iea-chief-receives-support-in-brusselsfor-modernisation-push.html>. 
In summary, the IEA's scope overlaps with that of IRENA. The two organizations deal with renewable energy, despite the fact that the IEA was not created for this purpose. In 2009 , the IEA could have let go of its renewable energy portfolio in response to the development of IRENA, but instead created a Renewable Energy division of its own. ${ }^{41}$ Agreements have been signed between the two organizations aiming at fostering cooperation and developing synergies rather than conflict. While recent comments by the IEA's Executive Director do not seem to go in that direction, perhaps too much is read into them, and cooperation, instead of competition, is still the key driver of the relationship between the IEA and IRENA.

\section{IRENA, IEA, and the UN SE4ALL Initiative}

In this section we consider whether the overlap between the IEA and IRENA can be seen as a challenge or an opportunity in the implementation of one of the most exciting recent developments in the international energy field: the SE4All Initiative.

\subsection{The SE4ALL Initiative}

The Initiative was launched by the UN Secretary-General in 2011. SE4All could be seen as a symbol of the momentum gained in the field of renewable energy. SE4All is a multi-stakeholder partnership among governments, the private sector, and civil society. It has three interlinked objectives, to be achieved by 2030: ensure universal access to modern energy services; double the global rate of improvement in energy efficiency; and double the share of renewable energy in the global energy mix. ${ }^{42}$ Moreover, in two related resolutions, ${ }^{43}$ the UN General Assembly first declared 2012 the 'International Year of Sustainable Energy for All', and then proclaimed the decade 2014-2024 the 'UN Decade of Sustainable Energy for All'. The second of the two resolutions stresses the 'need for a coherent, integrated approach to energy issues and the promotion of synergies across the global energy agenda for sustainable development' ${ }^{44}$

Because of its global vision and convening role as well as its worthwhile goalsparticularly in support of developing countries - SE4All enjoys the support of a high number of governments and organizations worldwide. ${ }^{45}$ What these UNGA resolutions and similar instruments offer is a timely and unique opportunity for all stakeholders to gather around a common platform to take further action to effectively move the world towards sustainable energy for all. Stakeholders have started to work with the UN towards a more coordinated global plan of action, in which activities will complement

\footnotetext{
${ }^{41}$ The Working Party on Renewable Energy Technologies was established by the IEA's Committee on Energy Research and Technology. Together with this working party, the Committee also established the Working Party on Fossil Fuels, the Working Party on Energy End-Use Technologies, and the Fusion Power Co-ordinating Committee.

42 Available at: $<$ http://www.se4all.org/our-vision/our-objectives/>.

${ }^{43}$ UNGA Resolution 65/151 on the International Year for Sustainable Energy for All, 2011, at $<$ http://www.un.org/en/ga/search/view_doc.asp?symbol=A/RES/65/151>; and Resolution 67/215, on the Promotion of new and renewable sources of energy, 2012, at $<$ http://www.un.org/en/ga/search/view_doc.asp?symbol=A/RES/67/215>.

${ }^{44}$ UNGA Resolution 67/215, on the Promotion of New and Renewable Sources of Energy, 2012, at $<\mathrm{http}$ //www.un.org/en/ga/search/view_doc.asp?symbol=A/RES/67/215>.

${ }^{45}$ Gonzalo Escribano, supra note 7.
} 
each other and synergies will be realized to help advance the overall objectives of sustainable energy for all. Programs relating to SE4All will also focus on synergies that could be realized as a result of the strong nexus between energy and other development factors, including water, food, health, education, gender, and poverty. ${ }^{46}$

SE4All operates through its Regional and Thematic Hubs which support the Initiative's goals, actions, projects, and programmes. ${ }^{47}$ One of the most important SE4All outcome so far is the development of a Global Tracking Framework, a tool designed to collect and regularly update energy data to support the Initiative in its three main areas of work (energy efficiency, renewable energy, and access to energy). The GTF is playing a significant role in monitoring progress made at the global level in the energy sector visà-vis the Initiative's three interlinked objectives listed above. ${ }^{48}$

\subsection{IRENA and IEA and their relationship with the SE4All Initiative}

Against this background, how do IRENA and the IEA relate to the SE4All Initiative? ${ }^{49}$ Despite the fact that IRENA stems from frustration with the UN's slow progress in the field of sustainable energy ${ }^{50}$ it has been chosen and tasked to represent SE4All's renewable energy hub. It has also been invited to explore how an aspirational target of doubling the global renewable energy share could be put into practice. ${ }^{51}$ Furthermore, even though IRENA is not currently part of the UN, such incorporation has been contemplated. ${ }^{52}$ IRENA's role in favouring international cooperation between and among the actors involved in the area of renewable energy may be its most significant contribution to the international community. By avoiding overlaps and duplications in the work performed by other intergovernmental organizations and initiatives (including the IEA), IRENA may become the main reference point for both developed and developing states when it comes to renewable energy.

Thus far, IRENA has been performing its tasks through its three dedicated structures: the Knowledge, Policy and Finance Centre ${ }^{53}$ the Country Support and Partnership Division; and the Innovation and Technology Centre. ${ }^{54}$ The first of these has developed

\footnotetext{
${ }^{46}$ UNGA Resolution 68/309, on the UN Decade of Sustainable Energy for All, 2013, at $<$ http://www.se4all.org/wp-content/uploads/2013/10/a-68-309-SG-report-on-the-Decade.pdf $>$.

${ }^{47}$ SE4All's Regional Hubs are the ones for Africa, Asia-Pacific, and Latin America and the Caribbean; its Thematic Hubs are Energy Efficiency, Energy Efficiency Facilitating Hub, Capacity Building (TERI), Renewable (IRENA) and the World Bank. For more information see 'Sustainable Energy for All, Our Hubs', at <http://www.se4all.org/hubs>.

${ }^{48}$ For the full and summary reports of the 2015 Global Tracking Framework see 'Sustainable Energy for All, Tracking Progress', at <http://www.se4all.org/tracking-progress $>$.

${ }^{49}$ See Lakshaman Guruswamy, 'International Energy Govenance: Introductory Remarks', in American Society of Int. Law Proceedings, 2012, 381. In his paper, the author provides a list of reasons for the fragmentation of international energy governance. Among those reasons, the creation of ' a multitude of organizations with competing and overlapping missions and perspectives' (among which the author includes IRENA) reflects the analysis of this paper.

${ }^{50}$ See Sybille Roehrkasten and Kirsten Westphal, supra note 18, at 3-4.

${ }^{51}$ Our Hubs, SE4All website, at $<$ http://www.se4all.org/hubs/irena/>.

52 Abbas Al Lawati, 'IRENA Keen to Join the UN Family, at

$<$ http://m.gulfnews.com/news/uae/environment/irena-keen-to-join-the-united-nations-family-1.491658 $>$.

${ }^{53}$ IRENA, "Knowledge, Policy and Finance Centre", at

$<\mathrm{http}$ ://irena.org/menu/index.aspx?mnu=cat\&PriMenuID $=35 \& \mathrm{C}$ atID=109>.

${ }^{54}$ IRENA, "IRENA Innovation and Technology Center", at
} 
the Global Renewable Energy Atlas, ${ }^{55}$ a global prospector for solar- and wind-energy potentials. The Country Support and Partnership Division, which is in charge of fostering renewable energy deployment in developing countries and intensifying cooperation, has launched the Renewable Readiness Assessment ${ }^{56}$ and the Global Renewable Energy Islands Network. ${ }^{57}$ The Innovation and Technology Centre has launched the Renewable Costing Alliance, ${ }^{58}$ established with private stakeholders; it is also in charge of designing and developing the Renewable Energy Roadmap (also known as REmap 2030) which provides 'a plan to double the share of renewable energy in the world's energy mix between 2010 and 2030,59 — an objective of the SE4All Initiative. Even though IRENA has been mainly fulfilling advisory roles, it has also provided concessional loans in developing countries by means of the IRENA/Abu Dhabi Fund for Development Project Facility. ${ }^{60}$

What is the role, if any, of the IEA in the SE4All Initiative? For this we must consider what sustainable energy means in the context of the Initiative. One approach would be to consider that only renewables are legitimate sources of sustainable energy. But this would respond to a narrow environmental dimension of sustainable energy and sustainable development in which climate change mitigation has a priority over other aspects of sustainable development. A different approach is to consider that sustainable energy in the context of SE4All includes a wider mix of energy sources. In fact, if the Initiative wishes to foster sustainable development in developing and least-developed countries, the promotion and deployment of renewables may not always be feasible. In such cases, reliance on traditional sources of energy can still be framed in the context of sustainable energy, as long as efforts are made to make them more efficient and, to the extent possible, cleaner. If that were the case, and if SE4All were to reflect such a broad interpretation of sustainable energy, there would be a role for the IEA in the implementation of the Initiative. Thus, if a least-developed country were to look to the SE4All for guidance on how to foster its natural resources (coal, oil, gas) in a 'sustainable' way, then good practices and guidelines stemming from the IEA may be useful. ${ }^{61}$ The IEA, however, has not been enlisted as one of SE4All's Thematic Hubs-

\footnotetext{
$<$ http://irena.org/menu/index.aspx?mnu=cat\&PriMenuID $=35 \& \mathrm{C}$ atID $=112>$.

${ }^{55}$ IRENA, "Global Atlas for Solar and Wind Energy" at

$<$ http://www.irena.org/menu/index.aspx?mnu=Subcat\&PriMenuID=35\&CatID=109\&SubcatID=163>.

56 IRENA, "Renewable Readiness Assessment", at

$<$ http://www.irena.org/menu/index.aspx?mnu=Subcat\&PriMenuID=35\&CatID=110\&SubcatID=164>.

${ }^{57}$ IRENA, Global Renewable Energy Islands Network, at $<$ http://grein.irena.org $>$.

${ }^{58}$ IRENA, Renewable Costing Alliance, at $<$ http://costing.irena.org/irena-renewable-costingalliance.aspx $>$.

${ }^{59}$ IRENA, REmap 2030 - A Renewable Energy Roadmap at <http://www.irena.org/remap/>.

${ }^{60}$ IRENA/ADFD, Supporting Energy Transition, at $<$ http://adfd.irena.org $>$.

${ }^{61}$ As far as renewable energy is concerned, besides its Working Party on Renewable Energy Technologies mentioned earlier in this paper, the IEA, inter alia, established the IEA Technology Collaboration Programmes; it designs and develops Technology Roadmaps; it produces Medium-Term Market Reports; it created the Policies and Measures Database for Global Renewable Energy; and launched the Grid Integration of Variable Renewables. Yet, the IEA Technology Collaboration Programmes also allow governments and industry to benefit from sharing resources and accelerating results towards 'cleaner' fossil-fuel-based solutions such as clean coal, carbon capture and storage, oil recovery, fluidized bed conversion, and other gas and oil technologies; see IEA, IEA Technology Collaboration Programmes, Fossil Fuels, at $<$ https://www.iea.org/tcp/fossilfuels/ $>$.
} 
in contrast with IRENA. Still, the IEA has been a leading participant in the creation of the 2015 version of the Global Tracking Framework, mentioned above.

It is important that the coordination between the SE4All and other major intergovernmental organizations like IRENA and IEA takes place and is effective in the context of the implementation of the SDGs. With the adoption of the latter in September $2015,{ }^{62}$ the legal and institutional landscape both for renewables and for sustainable energy becomes even more complex. There are at least two SDGs that require countries to focus on renewables. SDG 7-'Ensure access to affordable, reliable, sustainable and modern energy for all' - overlaps with the SE4All Initiative, whereas SDG 13- 'Take urgent action to combat climate change and its impacts'- has obvious implications for renewable as well as sustainable energy. ${ }^{63}$ Targets under SDG 7 reflect directly to the Initiative's objective to 'by 2030, increase substantially the share of renewable energy in the global energy mix ${ }^{964}$ and 'by 2030, double the global rate of improvement in energy efficiency'. ${ }^{65}$

We therefore have a situation of parallel implementation pathways for the SDGs and the SE4All Initiative. In this situation, coordination between IRENA (as the institutional hub for the Initiative) and the IEA is not merely optional but an urgent necessity if countries are to move together towards more sustainable energy and increased sustainable development. ${ }^{66}$ Zürn and Faude argue that 'it is not fragmentation per se, but rather the coordination (or lack of it) of fragmented or differentiated institutions that becomes the most important issue'. ${ }^{67}$ If so, fragmentation is not necessarily a negative phenomenon. It may reflect the complexity of today's society and global challenges. ${ }^{68}$

In summary, and to answer the question of whether the SE4All Initiative will provide an opportunity for IRENA and the IEA to deepen their collaboration, the analysis above shows that this will very much depend, among other things, on how one frames the very concept of sustainable energy.

\section{Conclusion}

The article has shown that the IEA and IRENA sit firmly in the current international energy landscape. However, their origins are very different, with the IEA born as a response to the energy crisis in the 1970s and IRENA arising from a vision for an increased role for renewables in a future low-carbon society. Other differences, such as membership rules, are also notable.

\footnotetext{
${ }^{62}$ On 25 September 2015, the UN General Assembly (A/RES/70/1) has formally adopted the new framework, 'Transforming Our World: the 2030 Agenda for Sustainable Development,' which is composed of 17 goals and 169 targets.

${ }^{63}$ However, most, if not all, other SDGs relate to energy in one way or another.

${ }^{64}$ Target 7.2.

${ }^{65}$ Target 7.3

${ }^{66}$ The scenario is even more complex if one adds the pressures and drivers for sustainable energy that stem from the outcome of the December 2015 UNFCCC Conference of the Parties, but for the purposes of this paper we are not considering such further developments.

${ }^{67}$ Michael Zürn and Benjamin Faude, Commentary, On Fragmentation, Differentiation, and Coordination Global Environmental Politics 13:3, August 2013, at 120.

${ }^{68}$ Ibid., at 120 .
} 
Despite their differences, this article has clarified that their scope overlaps, partly due to the decision of the IEA not to leave renewable energy promotion solely with IRENA. We have discussed whether unnecessary duplication of effort and conflict with the IEA, or positive synergy and coordination, is the more likely result of the implementation of the UN SE4All Initiative. A definitive answer is difficult, if not impossible, considering the early stage of such implementation. What can be said at this point is that, while SE4All sits squarely within IRENA, a potential role for the IEA cannot be ruled out. If a broad interpretation of sustainable energy is taken - one which includes fossil fuelsthe potential for involvement increases. Further complexity and a need for further coordination are created if the implementation of SE4All is considered alongside the implementation of the SDGs, in particular of the SDGs that relate to sustainable energy directly, or require promotion of renewables as a means to meet their targets. ${ }^{69}$

Finally, in an online press release preceding COP 21, the Director-General of IRENA Adnan Amin, and the IEA's Executive Director jointly stressed the important role that renewable technologies play in tackling issues such as energy security, environmental pollution, and climate change. In doing so, they stated that their two organizations 'are cooperating closely to help decision-makers realize the full potential that renewables can not only bring to our energy systems, but to our communities, our economies and our environment. ${ }^{70}$ This statement leads us to believe that IRENA and the IEA perceive cooperation, not competition, as the way forward in their relationship.

\footnotetext{
${ }^{69}$ In addition to these concluding remarks that summarise the points raised in this paper we wish to highlight that at the last International Renewable Energy Conference held in South Africa in October 2015, ministers and government representatives from 82 countries as well as representatives from the private sector including NGOs, academia, business and industry as well as international organisations and civil society have underlined the role that international cooperation plays in fostering renewable energy, energy efficiency and modern and sustainable energy access globally (SAIREC 2015, para. 30, at 8). In this regard, the participants have stressed, inter alia, that IRENA, the IEA, REN21, and contributors to these organisations shall closely collaborate 'on collecting streamlined renewable energy data globally,' policy development and best practice sharing (SAIREC 2015, para. 31, at 8). They have also praised, among other initiatives, the IEA Technology Network for being 'an effective catalyser for multilateral cooperation and for sharing best practices in renewable energies' (SAIREC 2015, para. 32, at 8). Thus, the international community seems to welcome the array of actors, initiatives and projects engaged in renewable energy development and deployment, provided that adequate cooperation and coordination is pursued.

${ }^{70}<$ http://money.cnn.com/2015/11/24/news/economy/renewable-energy-iea-cop21/index.html>.
} 